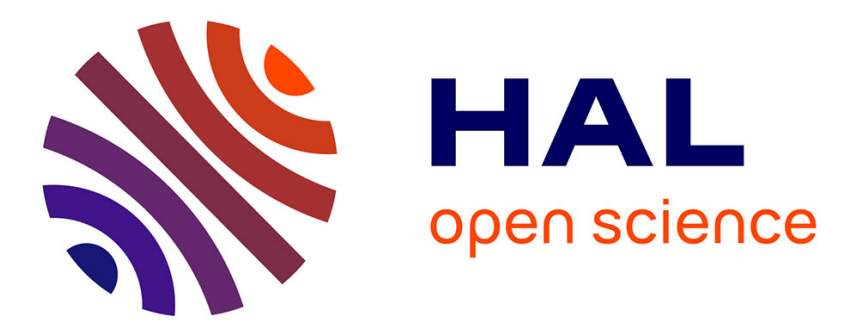

\title{
Potential unreliability of normal tissue as positive control in diagnostic immunohistochemistry of poorly differentiated carcinoma
}

\author{
Anurag Joshi, Murali Varma, Bharat Jasani, Sue Wozniac
}

\section{- To cite this version:}

Anurag Joshi, Murali Varma, Bharat Jasani, Sue Wozniac. Potential unreliability of normal tissue as positive control in diagnostic immunohistochemistry of poorly differentiated carcinoma. Histopathology, 2010, 57 (5), pp.760. 10.1111/j.1365-2559.2010.03692.x . hal-00593445

HAL Id: hal-00593445

https://hal.science/hal-00593445

Submitted on 16 May 2011

HAL is a multi-disciplinary open access archive for the deposit and dissemination of scientific research documents, whether they are published or not. The documents may come from teaching and research institutions in France or abroad, or from public or private research centers.
L'archive ouverte pluridisciplinaire HAL, est destinée au dépôt et à la diffusion de documents scientifiques de niveau recherche, publiés ou non, émanant des établissements d'enseignement et de recherche français ou étrangers, des laboratoires publics ou privés. 


\section{Potential unreliability of normal tissue as positive control in diagnostic immunohistochemistry of poorly differentiated carcinoma}

\begin{tabular}{|c|c|}
\hline Journal: & Histopathology \\
\hline Manuscript ID: & HISTOP-03-10-0150.R1 \\
\hline Manuscript Type: & Short Report \\
\hline $\begin{array}{l}\text { Date Submitted by the } \\
\text { Author: }\end{array}$ & 08-Apr-2010 \\
\hline Complete List of Authors: & $\begin{array}{l}\text { Joshi, Anurag; University Hospital of Wales, Histopathology } \\
\text { Varma, Murali; University Hospital of Wales, Histopathology } \\
\text { Jasani, Bharat; Cardiff University, Histopathology } \\
\text { Wozniac, Sue; University Hospital of Wales, Histopathology }\end{array}$ \\
\hline Keywords: & $\begin{array}{l}\text { immunohistochemistry, internal control, tumour differentiation, } \\
\text { prostate cancer }\end{array}$ \\
\hline
\end{tabular}

\section{$\mathrm{x}$}




\section{$\underline{\text { Title: }}$}

Potential unreliability of normal tissue as positive control in diagnostic immunohistochemistry of poorly differentiated carcinoma

\section{Authorship details:}

1. Dr. Anurag Joshi

MD (Path), DNB (Path), FRCPath

SpR Histopathology, Cardiff and Vale NHS Trust

Department of Histopathology

University Hospital of Wales

Cardiff CF14 4XW

dranuragjoshi@gmail.com

02920742712

Fax: 02920742701

2. Dr. Murali Varma (CORRESPONDING AUTHOR)

FRCPath, FCAP

Consultant Histopathologist, Cardiff and Vale NHS Trust

Department of Histopathology

University Hospital of Wales

Cardiff CF14 4XW

wptmv@cf.ac.uk

02920745316

Fax: 02920742701

3. Ms. Sue Wozniak

Biomedical Scientist, Cardiff and Vale NHS Trust

Department of Histopathology

University Hospital of Wales

Cardiff CF14 4XW 
Sue.wozniak@cardiffandvale.wales.nhs.uk

02920746320

Fax: 02920742701

4. Professor Bharat Jasani

$\mathrm{PhD}$, FRCPath

Professor of Pathology, Cardiff University

Department of Histopathology

University Hospital of Wales

Cardiff CF14 4XW

jasani@cardiff.ac.uk

02920742700

Fax: 02920744276

\section{$\underline{\text { Running title: }}$}

Lesson of the month

\section{Keywords:}

immunohistochemistry, internal control, tumour differentiation, prostate cancer 


\section{Lesson of the Month}

\section{Potential unreliability of normal tissue as positive control in diagnostic immunohistochemistry of poorly differentiated carcinoma}

Judicious use of positive and negative tissue controls is an important part of the technical quality assurance in immunohistochemistry. Positive controls may be 'external', where known positive tissue is immunostained in parallel to the test slide; or 'internal', with known positive tissue/ cells present within the tested tissue section. Internal controls are generally considered superior to external controls as the control cells have been subjected to identical conditions of fixation and immunostaining as the test cells. We describe 2 cases to demonstrate that even an apparently good quality internal control result is not adequate proof of assay sensitivity.

High-molecular weight cytokeratin (HMWCK) antibody clone $34 \beta \mathrm{E} 12$ is commonly used to help distinguish high-grade urothelial carcinoma from prostatic adenocarcinoma as it is consistently expressed by urothelial carcinoma but negative in prostate cancer ${ }^{1,2}$. The two cases described below were both referred to us for consultation with a differential diagnosis of urothelial vs. prostatic carcinoma. Tumour cells were judged to be immunonegative for prostatic markers as well as $34 \beta \mathrm{E} 12$ immunostaining (supported by adequately strong positive reactions observed in the internal control tissue elements). Despite this, unequivocal positivity for $34 \beta \mathrm{E} 12$ was observed using a more sensitive assay in our laboratory- indicating a diagnosis of urothelial carcinoma. 


\section{CASE HISTORIES}

\section{CASE 1}

Prostate needle biopsies performed on a 66 year old man with a 'malignant feeling' prostate and serum PSA $<0.1 \mathrm{ng} / \mathrm{L}$, revealed a poorly differentiated carcinoma (Fig 1-A) that was negative for immunohistochemical staining with PSA (Prostate Specific Antigen) and HMWCK (clone 34ßE12, DAKO, 1:50, Labvision autostainer, pretreatment with Trypsin for 12 minutes, $37^{\circ} \mathrm{C}, \mathrm{pH} 7.8$ ). The basal cells of adjacent benign prostate glands were strongly $34 \beta \mathrm{E} 12$ positive (Fig 1- B). The appearances were considered consistent with a high grade prostate carcinoma, however, in the absence of PSA staining, urothelial carcinoma could not be excluded and the case was referred to us.

At our institution, we confirmed the negativity for PSA and PSAP (prostate specific acid phosphatase). However, staining for HMWCK in our laboratory (clone 34ßE12; DAKO; 1:40; ChemMate/ HRP detection kit; microwave pre-treatment 800W 20min, EDTA pH7.0) revealed diffuse and intense staining of tumour cells (Fig 1- C). A diagnosis of high grade urothelial carcinoma was made and confirmed on a subsequent radical cysto-prostatectomy (Fig 1- D).

\section{CASE 2}

Transurethral resection of the prostate (TURP) performed on a 73-yearold man for urinary retention (PSA $1.5 \mathrm{ng} / \mathrm{L}$ ) showed a poorly differentiated carcinoma (Fig 2- A) that was negative for PSA, PSAP and HMWCK (clone 34ßE12, DAKO, Ventana autostainer, Protease 1 pretreatment) (Fig 2- B). Background benign urothelium was strongly $34 \beta E 12$ positive (Fig 2- B, inset). Because of this immunohistochemical 
profile, the origin of this tumour was considered uncertain and the case was referred for our further opinion.

Immunohistochemistry performed in our laboratory confirmed that the tumour cells were negative for PSA and PSAP, however, HMWCK (clone 34ßE12; DAKO; 1:40; ChemMate/ HRP detection kit; microwave pre-treatment 800W 20min, EDTA pH7.0) stained the tumour cells diffusely and intensely (Fig 2- C). The immunohistochemical staining profile was thus interpreted as in keeping with high-grade urothelial carcinoma.

Two months after the TURP, the patient expired because of unrelated medical causes. There had been no clinical, serological or radiological evidence of prostate cancer.

\section{COMMENT}

Positive controls are used to exclude false negative results resulting from suboptimal immunostaining assay performance. In the two cases presented, 34ßE12 immunostaining had been considered satisfactory due to strong immunoreactivity in the internal positive control tissue. However, the original immunohistochemical method used in these two cases has been shown to be suboptimal with respect to the sensitivity of 34ßE12 immunostaining as an urothelial marker (a heat induced antigen retrieval method is preferred to enzyme predigestion in this scenario) ${ }^{3}$.

The cases highlight an important issue regarding reliance upon internal positive controls in routine immunohistochemistry. Internal controls are generally regarded as superior to external controls by virtue of these 'control' cell populations having been subjected to identical fixation as the tumour cells being investigated. In these cases, although the original 
34ßE12 immunostaining showed strong positivity in the positive internal controls (basal cells of benign prostatic acini in case 1 and benign urothelium in case 2) the urothelial carcinoma cells were falsely negative, as subsequently shown by a more sensitive method. The sensitivity of $34 \beta E 12$ as an urothelial marker has been shown to be higher with heat retrieval pre-treatment as used in our laboratory as compared to enzyme pre-digestion that had been employed in the referring laboratories ${ }^{3}$.

Internal positive controls are most reliable when they are similar in their antigen content and distribution to the "tumour cells". Under these circumstances, the quality control of assay sensitivity afforded by them is considered ideal; as is the case when $34 \beta E 12$ is used as a basal cell marker to support the diagnosis of prostatic adenocarcinoma (where the basal cells of benign prostatic glands serve as the internal control).

It should be noted that the same issues would also apply to external positive controls. The external positive control tissue must be appropriate to the tissue being tested. Thus, when $34 \beta E 12$ is used as a prostatic basal cell marker, benign prostate would be a suitable internal/external positive control. However, if the same antibody is used as an urothelial marker, the ideal external control would be high-grade urothelial carcinoma. 


\section{Figure 1}

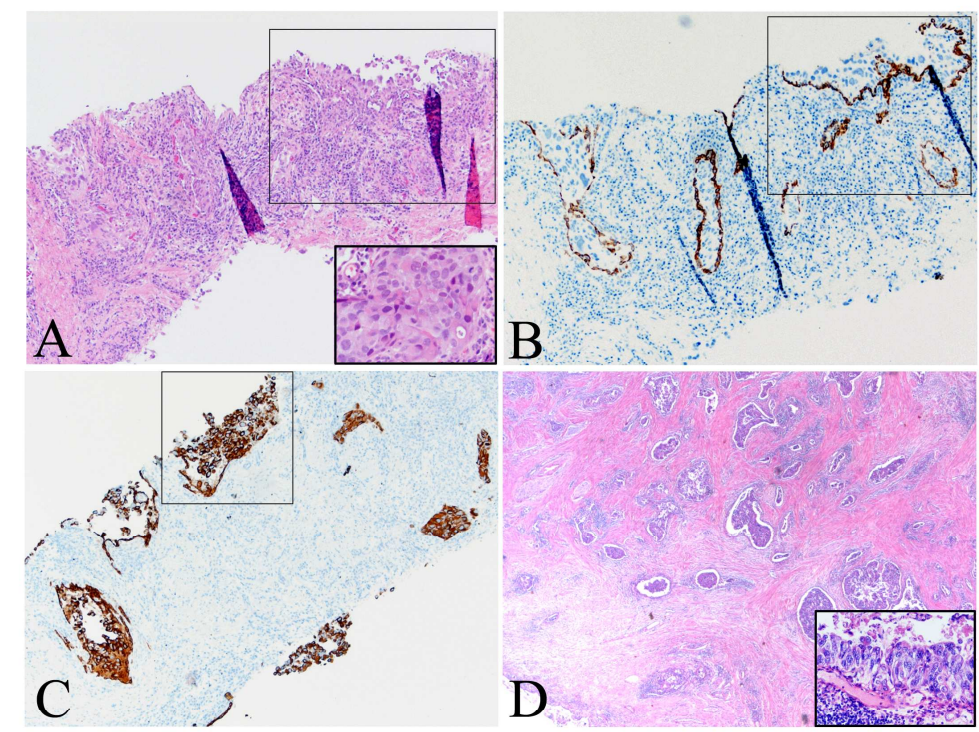

Fig 1

A) Prostate biopsy with poorly differentiated carcinoma (H\&E)

B) Tumour cells are negative on 34ßE12 immunostaining after enzyme predigestion, note positive staining in prostatic basal cells (internal control)

C) Diffusely positive tumour cells on 34BE12 immunostaining after heat mediated antigen retrieval.

D) Follow-up cystectomy specimen showing invasive urothelial carcinoma and urothelial carcinoma in situ (inset) (H\&E)

$209 \times 297 \mathrm{~mm}(300 \times 300$ DPI $)$ 
Figure 2

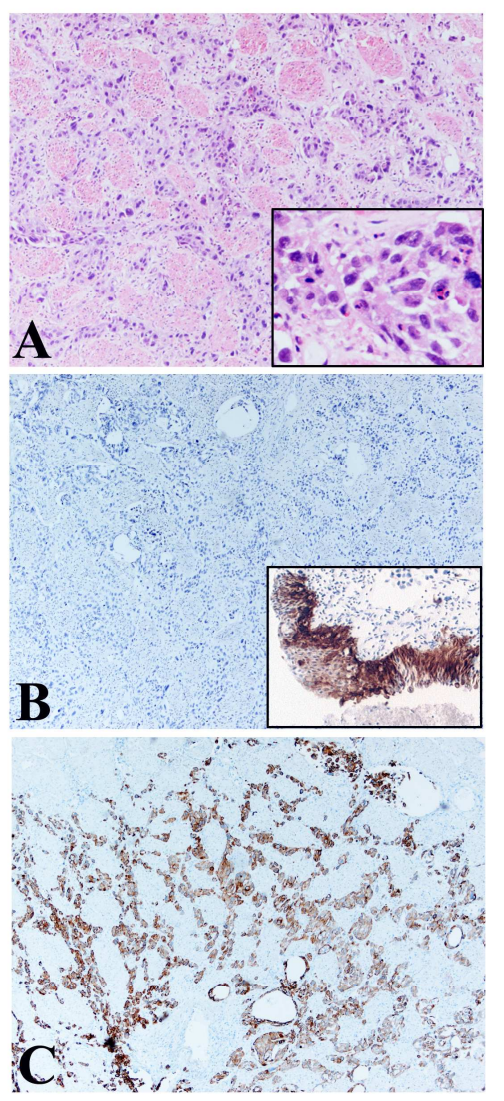

Fig 2

A) TURP specimen with poorly differentiated carcinoma (H\&E)

B) Tumour cells are negative on 34BE12 immunostaining after enzyme predigestion, note the strongly positive staining in normal urothelium present elsewhere in the section (inset).

C) Tumour cells diffusely positive on 34ßE12 immunostaining after heat mediated antigen retrieval.

$209 \times 297 \mathrm{~mm}(300 \times 300 \mathrm{DPI})$ 


\section{FIGURE LEGENDS}

Fig 1

A) Prostate biopsy with poorly differentiated carcinoma (H\&E)

B) Tumour cells are negative on 34ßE12 immunostaining after enzyme predigestion, note positive staining in prostatic basal cells (internal control)

C) Diffusely positive tumour cells on 34ßE12 immunostaining after heat mediated antigen retrieval.

D) Follow-up cystectomy specimen showing invasive urothelial carcinoma and urothelial carcinoma in situ (inset) (H\&E)

Fig 2

A) TURP specimen with poorly differentiated carcinoma (H\&E)

B) Tumour cells are negative on 34ßE12 immunostaining after enzyme predigestion, note the strongly positive staining in normal urothelium present elsewhere in the section (inset).

C) Tumour cells diffusely positive on $34 \beta E 12$ immunostaining after heat mediated antigen retrieval.

\section{REFERENCES}

1. Varma, M. Jasani, B. Diagnostic utility of immunohistochemistry in morphologically difficult prostate cancer: review of current literature. Histopathology. 2005; 47(1):1-16.

2. Chuang AY, Demarzo AM, Veltri RW, et al. Immunohistochemical differentiation of high-grade prostate carcinoma from urothelial carcinoma. Am J Surg Pathol. 2007; 31(8): 1246-55.

3. Varma M, Morgan M, Amin MB, et al. High molecular weight cytokeratin antibody (clone 34ßE12): a sensitive marker for differentiation of high-grade invasive urothelial carcinoma from prostate cancer. Histopathology. 2003; 42: 167-72. 